\title{
Ogólnopolskie czasopisma andragogiczne w okresie międzywojennym (1918-1939)
}

\begin{abstract}
Abstrakt
W tekście podjęto próbę ukazania roli czasopism andragogicznych w upowszechnianiu edukacji dorosłych w okresie międzywojennym. Scharakteryzowano sześć ogólnopolskich pism odzwierciedlających profil społeczno-ideologiczny państwa i organizacji, które je wydawały. Na ich łamach prezentowano opracowania teoretyczne oraz metodyczne ułatwiające pracę z człowiekiem dorosłym. Ich głównym zadaniem było wspieranie nauczycieli i oświatowców w pracy szkolnej i pozaszkolnej z dorosłymi. Podstawę do przygotowania tekstu stanowiła analiza treści periodyków.
\end{abstract}

Słowa kluczowe: oświata pozaszkolna dorosłych, czasopisma andragogiczne, uczeń dorosły.

\section{All-Polish Andragogical Journals in the Interwar Period (1918-1939)}

\begin{abstract}
In the article, the author attempts to show the role of andragogical journals in popularizing adult education in the Interwar period. Six Polish journals of nationwide circulation are characterized, as they reflected the socio-ideological profile of the state and the organizations which published them. In their columns, theoretical and methodological studies which facilitated work with adults were presented. Their major task was to support teachers and educators in their school and outside-school work with adult learners. The basis for preparing the present text was an analysis of the content of the periodicals.
\end{abstract}

Keywords: outside-school education for adults, andragogical journals, adult learners.

\footnotetext{
* Uniwersytet Opolski.

Artykuł otrzymano: 20.01.2020; akceptacja: 20.04.2020.
} 


\section{Początki czasopism andragogicznych}

Początki wydawania periodyków podejmujących problemy związane z kształceniem, dokształcaniem, aktywnością kulturalną sięgają ostatnich lat XIX stulecia. Pierwszym polskim czasopismem, analizującym zagadnienia związane z oświatą dorosłych była „Wiedza dla Wszystkich” - organ Uniwersytetu Ludowego im. A. Mickiewicza - wydawana we Lwowie w latach 1899-1900. Poruszano w niej problemy z zakresu teorii oświaty dorosłych, jej ideologii, organizacji i metod. Czasopismo zawierało wzory wykładów popularnych, zwłaszcza z zakresu nauk społecznych, przyrodniczych, higieny i sztuki. Prezentowano w nim kronikę życia uniwersytetów ludowych i całego TUL. Jednakże na skutek trudności finansowych czasopismo upadło zaledwie po dwóch latach wydawania (Możdżeń, Musiał 1981: XVI). W Krakowie w 1899 r. ukazała się „Oświata” poświęcona zagadnieniom wykształcenia, czytelnictwa i samouctwa, ale w 1902 r. zakończono jej wydawanie. Utworzonymi na początku XX w. czasopismami, których wydawanie kontynuowano w latach międzywojennych, były organy: Towarzystwa Szkoły Ludowej „Przewodnik Oświatowy” wydawany w latach 1901-1939 oraz „Przegląd Oświatowy” z lat 1910-1939 - Towarzystwa Czytelni Ludowych (tamże).

Powstanie niepodległego państwa polskiego w 1918 r. znacznie ożywiło ruch wydawniczy na terenie całego państwa. Część pism pedagogicznych, społeczno-politycznych, kulturalnych - w tym podejmujących problematykę oświaty pozaszkolnej - ukazujących się do tej pory $\mathrm{z}$ inicjatywy towarzystw społeczno-oświatowych - nadal była wydawana i dostępna na terenie całego państwa. Powstało również wiele nowych - zarówno z inicjatywy władz państwowych, jak i samorządowych, wydawanych czasami nieregularnie bądź krótko. W odmiennych pod względem wykształcenia ludności regionach Polski, jak i zróżnicowanych możliwościach dostępu do dóbr kulturalnych, istotnym zadaniem było wspieranie poprzez czasopiśmiennictwo nauczycieli w ich pracy pedagogicznej nie tylko z dziećmi i młodzieżą, ale też z dorosłymi. To ich działalność w środowisku lokalnym miała przyczyniać się do rozbudzania i rozwoju, ale również do realizacji potrzeb oświatowych. Za ich pomocą rozpowszechniano nowe idee edukacyjne oraz doświadczenia praktyki innych krajów. Na ich łamach przedstawiciele środowiska naukowego prezentowali własne poglądy. W ten sposób prasa pedagogiczna stawała się istotnym czynnikiem w poszerzaniu i pogłębianiu wiedzy teoretycznej oraz metodycznej wśród oświatowców. Wpływała również na inspirowanie przemian społecznych związanych z rolą edukacji w podnoszeniu rozwoju gospodarczego państwa.

U progu niepodległości praca oświatowa pozaszkolna była ważnym czynnikiem budowania jedności kultury i integrowania społeczeństwa polskiego. Wydawane wówczas czasopisma są źródłem o ówczesnych zagadnieniach, związanych z oświatą dorosłych, problemach, z którymi borykało się zarówno państwo polskie, nauczyciele jak i oświatowcy. 
W całym okresie międzywojennym ukazywały się następujące ogólnopolskie czasopisma andragogiczne ${ }^{1}$ :

- „Oświata Pozaszkolna” w latach 1921-1923, której redaktorem był dr Eustachy Nowicki, wydawana przez Ministerstwo Wyznań Religijnych i Oświecenia Publicznego;

- „Polska Oświata Pozaszkolna” od 1924 do 1934 r., początkowo organ Związku Polskiego Nauczycielstwa Szkół Powszechnych, a następnie po zjednoczeniu tej organizacji ze Związkiem Zawodowym Nauczycielstwa Polskich Szkół Średnich w 1930 r. - organ Związku Nauczycielstwa Polskiego. Był to dwumiesięcznik redagowany najpierw przez Eustachego Nowickiego, a następnie od roku 1929 przez Aleksandra Patkowskiego;

- „Przewodnik Pracy Społecznej” wydawany przez ZNP od 1934 do 1939 r. - kontynuujący problematykę „Polskiej Oświaty Pozaszkolnej”; redaktorem naczelnym został Kazimierz Maj - działacz ruchu ludowego i nauczyciel;

- „Przegląd Oświatowy” od 1910 r. organ Towarzystwa Czytelni Ludowych redagowany przez ks. Antoniego Ludwiczaka. Był to miesięcznik wydawany do 1939 r.;

- „Przewodnik Oświatowy” wydawany w Krakowie od 1901 r. do 1939 - organ Towarzystwa Szkoły Ludowej, dwumiesięcznik redagowany przez Andrzeja Nowaka, a następnie Mariana Stępowskiego ;

- „Oświata Polska” - dwumiesięcznik wydawany w latach 1924-1939, organ Wydziału Wykonawczego Zjednoczenia Polskich Towarzystw Oświatowych pod redakcją Józefa Stemlera;

- „Praca Oświatowa” - miesięcznik wydawany w latach 1935-1939 przez Ludowy Instytut Oświaty i Kultury w Warszawie, którego redaktorem początkowo była Jadwiga E. Baranowska, a następnie Antoni Konewka.

Podstawę do przygotowania poniższego tekstu stanowiła analiza zawartości merytorycznej ukazujących się w okresie międzywojennym wyżej wymienionych ogólnopolskich pism andragogicznych. Problematyka ta do tej pory nie była całościowo podejmowana i nadal jest traktowana marginalnie, o czym świadczy fakt ukazania się od 1945 r. jedynie kilku artykułów jej dotyczących (Breitkopff 1986; Kozdrowicz 1987; Michalski, Michalska 2017; Wroczyński 1983; Lubczyńska 2014; Sapia-Drewniak 2019).

\section{Kontynuacja przedwojennego czasopiśmiennictwa oświatowego}

Organizujące w okresie zaborów działalność pozaszkolną organizacje, takie jak Towarzystwo Czytelni Ludowych na terenie zaboru pruskiego, Towarzystwo Szkoły Ludowej w Galicji i Polska Macierz Szkolna - w Królestwie Polskim kontynuowały

\footnotetext{
1 Poza czasopismami andragogicznymi o ogólnokrajowym zasięgu wydawano periodyki lokalne. Również w czasopismach ogólnopedagogicznych niejednokrotnie podejmowano zagadnienia związane z pozaszkolną oświatą dorosłych. Nie są one jednak przedmiotem analizy w niniejszym opracowaniu.
} 
ją po powstaniu niepodległego państwa polskiego. W pierwszych powojennych latach dla tych organizacji istotne było utrzymanie związku z dotychczasową tradycją edukacji pozaszkolnej oraz świadome wychowanie narodowo-patriotyczne zróżnicowanego polskiego społeczeństwa. Zadania państwa borykającego się po odzyskaniu niepodległości z wieloma trudnościami, w tym gospodarczymi i finansowymi, spowodowały, iż nie było jednomyślności między tymi organizacjami a Ministerstwem Wyznań Religijnych i Oświecenia Publicznego (MWRiOP) w kwestii organizowania oświaty pozaszkolnej.

Już podczas zjazdu oświatowego w Warszawie w dniach 14-17 kwietnia 1919 r. wskazywano, iż oświata pozaszkolna miała być jednym z ważnych działów edukacji. Aleksander Janowski reprezentujący Wydział Oświaty Pozaszkolnej MWRiOP podczas jego trwania nakreślił szeroki zakres pracy oświatowej w dziedzinie walki $\mathrm{z}$ analfabetyzmem, rozwijania czytelnictwa, kształcenia narodowego i obywatelskiego ludności oraz podnoszenia poziomu kulturalnego polskiego społeczeństwa. Jako zadanie oświaty dorosłych wskazano „uświadomienie narodowe i obywatelskie tych ludzi, którzy nie przechodzili szkół, lub też przechodzili je dawno, lub wreszcie uczyli się w szkołach tych, celowo pozbawionych czynnika narodowego" (Kopczewski 1920: 64). Rezultatem tej działalności miała być wspólnota i jedność kulturalna całego narodu. Reprezentujący MWRiOP A. Janowski stwierdził podczas zjazdu, iż:

pomyślne przeprowadzenie swoich zadań oświata pozaszkolna musi opierać przede wszystkim na inicjatywie społecznej. Jeżeli bowiem przy organizowaniu szkolnictwa decyduje jedna ogólna zasada powszechnego nauczania, to $\mathrm{w}$ sprawie oświaty pozaszkolnej tyle jest różnorodnych i powikłanych czynników, że centralna władza państwowa nie może łatwo orientować się w nich ani narzucać dyspozycji (tamże).

Państwo zaś miało m.in. „popierać ją materialnie i moralnie oraz udzielać porad i wskazówek" (tamże). Dyskusja ta trwała - w różnym natężeniu, przez całe 20-lecie międzywojenne. Mające bogate doświadczenie organizacyjne w zakresie oświaty dorosłych towarzystwa swoją działalność opierały na dotychczasowych, sprawdzonych metodach. One już w okresie zaborów wydawały czasopisma związane z problematyką oświaty pozaszkolnej, a utworzenie państwa polskiego nie przerwało tejże.

W latach 1923-1928 w polskim rządzie dominowała opcja endecka, co w sposób bezpośredni wpłynęło na zamierzenia naczelnych władz szkolnych w zakresie kształcenia dorosłych. Pod wpływem endecji pozostawały organizacje społeczne prowadzące swoją działalność w okresie przedwojennym. Na nich też spoczywała organizacja oświaty pozaszkolnej na terenie całego państwa. Wydział Oświaty Pozaszkolnej MWRiOP nie koordynował pracy oświatowej, jak również jej nie finansował. Konsekwencją było wzmocnienie się i uaktywnienie dotychczasowych 
organizacji. Przedwojenne towarzystwa oświatowe pod koniec 1923 r. rozpoczęły działania mające na celu zjednoczenie i wspólne działanie (Sutyła 1982: 56). Efektem było utworzenie Zjednoczenia Polskich Towarzystw Oświatowych, którego Wydział Wykonawczy miał koordynować prace w duchu chrześcijańskim i narodowym. Koncentrowano się na upowszechnianiu czytelnictwa, tworzeniu bibliotek, uniwersytetów niedzielnych, szkół społeczno-obywatelskich i działalności kulturalno-oświatowej. Powołano też nowe czasopismo o problematyce związanej z oświatą pozaszkolną „Oświata Polska”.

Przez cały okres międzywojenny kontynuowano wydawanie periodyków największych organizacji oświatowych ukazujących się od początku wieku XX, których zasięg znacząco się zwiększył, obejmując nie tylko tereny byłych zaborów, ale obszar całego państwa.

Początki „Przeglądu Oświatowego”, organu Towarzystwa Czytelni Ludowych redagowanego przez ks. Antoniego Ludwiczaka, sięgają 1910 r. Był to miesięcznik poświęcony sprawom oświatowym i kulturalnym wydawany do 1939 r., którego problematyka koncentrowała się wokół czytelnictwa i bibliotek. Była to broszurka licząca około 20 stron. Niektóre numery były w całości wydrukowanym sprawozdaniem z pracy TCL i rozliczeniem budżetu towarzystwa. Jej odbiorcami byli bibliotekarze i organizatorzy różnych form pracy pozaszkolnej.

Podobnie „Przewodnik Oświatowy”, organ Towarzystwa Szkoły Ludowej, ukazywał się w latach 1900-1939. Były to kilkunastostronicowe broszurki zawierające treści wyłącznie dotyczące tego stowarzyszenia. Na jego łamach upowszechniano instytucjonalne formy pracy oświatowej oraz samokształcenie, a adresatem byli działacze TSL-u. Po powstaniu niepodległego państwa polskiego skoncentrowano się na oświacie dorosłych, bowiem zagadnienia szkolnictwa przejęło państwo polskie („Przewodnik Oświatowy” 1920: 23). W latach 30. XX w. drukowano treści dotyczące zarówno tradycyjnego nauczania elementarnego dorosłych, kursów nauki początkowej, jak i samokształcenia, ruchu świetlicowego czy uniwersytetów niedzielnych.

\section{Nowe czasopisma andragogiczne}

Po powstaniu niepodległego państwa polskiego od roku 1918 główny kierunek pracom oświatowym nadawał Wydział Oświaty Pozaszkolnej MWRiOP. Uznano wówczas oświatę pozaszkolną za jedno z ważniejszych zadań resortu. Miał on dalsze prace w tym zakresie koordynować, pogłębiać i rozszerzać. Wydział zapoczątkował konferencje oświatowe, kursy dla pracowników oświatowych, utworzono Pracownię Oświaty Pozaszkolnej oraz zaczęto wydawanie własnego organu prasowego.

Pierwszym nowo powstałym czasopismem, dotyczącym zagadnień oświaty dorosłych była „Oświata Pozaszkolna”, którą rozpoczęto wydawać w 1921 r. ze 
środków MWRiOP. Periodyk miał za zadanie integrację narodu oraz kształtowanie postawy narodowej i obywatelskiej (Od Redakcji 1921: 3). Funkcję redaktora powierzono doktorowi Eustachemu Nowickiemu. Wydział Oświaty Pozaszkolnej systematycznie organizował od października 1920 r. w różnych miastach całej Polski konferencje oświatowe, a po ich zakończeniu wydawano biuletyn, którego adresatami były osoby zaangażowane $\mathrm{w}$ prace $\mathrm{z}$ dorosłymi, niebiorące udziału w konferencjach. Chciano w ten sposób upowszechniać informacje mogące pomagać i wspierać prowadzących pracę oświatową na terenie Rzeczypospolitej. W opracowaniach opublikowanych na łamach czasopisma odzwierciedlone zostały kierunki prac oświatowych Wydziału Oświaty Pozaszkolnej MWRiOP, czyli alfabetyzacja, czytelnictwo i uświadomienie narodowo-obywatelskie. Były to w owym czasie najważniejsze cele polityki oświatowej wobec dorosłych obywateli Rzeczypospolitej.

Na charakter i specyfikę każdego czasopisma wpływ mają autorzy publikowanych na jego łamach tekstów. Do współpracy z „Oświatą Pozaszkolną” zaproszono zarówno wybitnych teoretyków, jak i praktyków oświaty pozaszkolnej ówczesnych czasów. Swoje teksty publikowali przedstawiciele różnych dyscyplin naukowych m.in. Helena Radlińska, Józefa Joteyko (psycholog), Jan Bystroń (muzykolog), Czesław Jaxa-Bykowski, Władysław Wolert (historyk dziennikarstwa) oraz działacze oświatowi, tacy jak m.in. ks. Antoni Ludwiczak, Kazimierz Korniłowicz (Centralne Biuro Kursów dla Dorosłych), Eustachy Nowicki, Emmanuel Imiela (referent oświaty pozaszkolnej w Wydziale Oświaty Publicznej Województwa Śląskiego). Zapraszano również praktyków z zagranicy do przybliżenia polskiemu czytelnikowi instytucji oświatowych kierowanych do dorosłych.

Z dniem 31 grudnia 1923 r. „Oświata Pozaszkolna” przestała się ukazywać, co było wynikiem skarbowych reform ministra Stanisława Grabskiego, który znacząco ograniczył budżet ministerstwa. Redukcje budżetowe najbardziej dotknęły oświatę pozaszkolną (Banaczkowski 1962: 495). Samo czasopismo w trudnym okresie początkowych lat Drugiej Rzeczypospolitej integrowało oświatę pozaszkolną kierowaną do dorosłych, przybliżało światowe osiągnięcia, inspirując do wykorzystania zagranicznych doświadczeń i sprawdzonych rozwiązań w tym zakresie (Sapia-Drewniak 2019: 200).

Po likwidacji ministerialnego periodyku „Oświaty Pozaszkolnej” na Zjeździe Związku Polskiego Nauczycielstwa Szkół Powszechnych we wrześniu 1923 r. w Warszawie zajęto się również aktualnymi problemami oświaty pozaszkolnej. Wydział Wykonawczy tej organizacji w lutym 1924 r. zatwierdził dokument dotyczący oświaty pozaszkolnej. Jednym z postanowień było powołanie pisma „Polska Oświata Pozaszkolna”, którego redaktorem został dr Eustachy Nowicki - wcześniej redaktor „Oświaty Pozaszkolnej” (Breitkopff 1983: 498). Na łamach pisma - zgodnie z celem pracy oświatowej ZPNSP - dążono do przebudowy życia społecznego, czyli włączenia szerokich kręgów społecznych do budowy demokratycznego państwa. Do tego zadania należało przygotować społeczeństwo poprzez przekazy- 
wanie wiedzy i aktywizację społeczną (tamże). Istotnym zagadnieniem było przygotowanie nauczycieli szkół ludowych do pracy z dorosłymi. Przemiany życia politycznego i gospodarczego - pisano -„wysuwały nowe zadania i konieczności przewartościowania wielu utartych pojęć, zastosowania odmiennych metod na polu tzw. oświaty pozaszkolnej”. Oświata pozaszkolna „(...) ma stwarzać warunki dla rozwoju sił twórczych jednostek i grup, podnoszących ich zasób etyczny i umysłowy" (Nasze dziesięciolecie 1933: 2).

Nauczyciele pracujący w środowiskach wiejskich i małomiasteczkowych realizowali to zadanie poprzez tworzenie kursów nauczania początkowego dla dorosłych, zgodnie z opracowanym programem przez tę organizację. Jak już wcześniej wspomniano, najpoważniejszym problemem II Rzeczypospolitej był analfabetyzm obejmujący prawie połowę obywateli, stąd pierwszoplanowym celem była jego likwidacja. Dzięki aktywności nauczycieli utworzono kilkaset bibliotek, czytelń, świetlic oraz prowadzono działalność kulturalno-oświatową (Banaczkowski 1962: 495). Redakcja pisma współpracowała ze środowiskiem naukowym, którego przedstawiciele przygotowywali artykuły o charakterze ogólnopedagogicznym i andragogicznym. Niezwykle pomocne dla organizatorów oświaty pozaszkolnej były opracowania dotyczące nauczyciela i stosowanych przez niego metod pracy z osobami dorosłymi. Efektem ich pracy miało być ukształtowanie jednostki samodzielnie myślącej, aktywnej społecznie i bezinteresownej w działaniu społecznym (Breitkopff 1983: 502). Od 1933 r. „Polska Oświata Pozaszkolna” ukazywała się jako miesięcznik, a zarazem bezpłatny dodatek do „Głosu Nauczycielskiego” (tamże).

Po zaprzestaniu wydawania „Polskiej Oświaty Pozaszkolnej” jej miejsce od września 1934 r. zajęło nowe czasopismo ZNP „Przewodnik Pracy Społecznej”. Ukazywało się do 1939 r. Miało ono kontynuować zadania i cele „Polskiej Oświaty Pozaszkolnej”, a zmiana tytułu wiązała się z „dostosowaniem pisma do potrzeb nauczyciela jako pracownika społecznego" (Kozdrowicz 1987: 202). Jak napisano w pierwszym numerze:

Chcemy, żeby „Przewodnik Pracy Społecznej” był jednym z głównych środków a/ przygotowania nauczycielstwa do pracy społecznej i był doradcą w tej dziedzinie, b/ współudziału nauczycielstwa w procesie tworzenia polskiej myśli społeczno-wychowawczej, oświatowej, kulturalnej i gospodarczej (tamże: 199).

Redaktorem naczelnym został Kazimierz Maj, członek Zarządu Głównego ZNP, ale również działacz ludowy i nauczyciel. Przez okres trzech lat współredaktorem pisma był Jan Nowak przedstawiciel ZNP w zarządzie Towarzystwa Popierania Budowy Publicznych Szkół Powszechnych.

Kolejne czasopismo o zasięgu ogólnopolskim „Oświata Polska” była organem Polskich Towarzystw Oświatowych, a jej pierwszy numer ukazał się w $1924 \mathrm{r}$. Towarzystwo to skupiało organizacje społeczno-oświatowe powstałe w okresie 
zaborów. Celem pracy oświatowej według działaczy tych organizacji - a przede wszystkim Wydziału Wykonawczego Polskich Towarzystw Oświatowych - było szerzenie oświaty w duchu narodowym. Idee oświaty narodowej były pierwszoplanowymi. Naczelnym zadaniem pracy kulturalno-oświatowej było pogłębianie świadomości narodowej, szerzenie wiedzy, a w tym wiedzy obywatelskiej, zapoznawanie z kulturą polską (Stemler 1924: 11). Zamieszczano na jej łamach artykuły traktujące o metodach pracy oświatowej. W ten sposób chciano zachęcić do współpracy wszystkich obywateli państwa. Niezwykle istotna była walka z analfabetyzmem według redakcji obejmującym wówczas 50\% polskiego społeczeństwa. Wynikającym z tego drugim zagadnieniem było tworzenie instytucji zapobiegających powrotnemu analfabetyzmowi przez umożliwienie rozwoju intelektualnego (tamże). Przez cały okres międzywojenny (wydawano je do roku 1939) redagował pismo Józef Stemler kierujący Polską Macierzą Szkolną. Było ono ściśle powiązane politycznie z Narodową Demokracją.

Od marca 1935 r. w Warszawie Instytut Oświaty Dorosłych, Instytut Teatrów Ludowych, Poradnia Biblioteczna, Powszechny Uniwersytet Korespondencyjny zaczęły wydawanie „Pracy Oświatowej”. Redaktorem pisma początkowo była Jadwiga E. Baranowska, a od numeru 6-7 tego roku - Antoni Konewka. W trakcie roku kalendarzowego ukazywało się 10 numerów - z przerwą w okresie wakacyjnym. Pierwszy rocznik miał łącznie 576 stron, tzn., iż przeciętnie każdy numer miał około 60 stron. W okresie wydawania periodyku oświata pozaszkolna - obok systemu szkolnego - była drugim torem oświaty obejmującym swoim zasięgiem młodzież dorastającą i dorosłych. Jak napisał R. Wroczyński, „był to tor autonomiczny, realizował własne ambitne cele i programy. (...) Siłę napędową rozwoju oświaty pozaszkolnej stanowiły szybkie przeobrażenia społeczne kraju, ruch emancypacyjny na wsi, dynamizm młodej inteligencji wychowanej w niepodległym państwie" (Wroczyński 1983: 161).

\section{Struktura periodyków i ich zawartość merytoryczna}

W latach 20. XX w. ukazujące się czasopisma andragogiczne - zarówno kontynuujące pracę z okresu przedwojennego, jak i nowo powstałe, na swoich łamach starały się uświadamiać czytelnikom ich obywatelskość i przynależność do narodu polskiego. Dominował wówczas ideał wychowania narodowego - zarówno w edukacji szkolnej, jak i pozaszkolnej. Władysław Radwan pisał wówczas:

Chodzi o to, żeby przy największych nawet różnicach wyksztalcenia i poziomie życia duchowego ludzie mieli możność porozumieć się w sprawach najważniejszych, dotyczących celu, sensu, sposobu życia jednostki oraz sposobu organizowania współżycia społecznego. Chodzi o wspólny w tych sprawach język pojęć, o wytwarzanie poczucia wspólnego użytkowania 
dorobku kulturalnego oraz współudziału w tworzeniu kultury, chodzi o jedność kulturalną w narodzie, a w sprawach najbardziej istotnych - wśród narodów świata (Radwan 1925: 18).

Takie cele były realizowane poprzez treści publikowane w tym okresie na łamach wszystkich ogólnopolskich periodyków andragogicznych. Głównie dotyczyło to organizacji społecznych z czasów przedwojennych, które nieprzerwanie prowadziły swoją działalność. Prezes TCL ks. A. Ludwiczak wskazywał, iż praca pozaszkolna z dorosłymi prowadzona przez tę organizację dąży do integrowania, a nie dzielenia społeczeństwa, dlatego chciała skupiać ludzi o różnych poglądach politycznych. Ale fundamentalne dla TCL było oparcie swych zasad ideowych na tym, iż jest to organizacja polska (narodowa) i katolicka (Sławińska 1989: 67). Takie rozumienie zadań pozaszkolnej oświaty dominowało na łamach „Przeglądu Oświatowego”.

Redakcja „Oświaty Pozaszkolnej” - organu MWRiOP w pierwszym numerze napisała:

Rozpoczynając wydawnictwo pisma, poświęconego zagadnieniu dorosłych, zamierza Wydział Oświaty Pozaszkolnej uczynić zadość palącej potrzebie stworzenia centralnego organu, któryby miał za zadanie łączyć i wiązać w harmonijną całość wszystkie, tak dotąd rozbieżne poczynania oświatowe, a równocześnie z tym być warsztatem $\mathrm{w}$ dokonywującej się pracy nad ustaleniem celów, kierunków i metod naszej oświatowej działalności (Od Redakcji 1921: 2).

I dalej:

...pragnie ono także stać się kuźnicą dla wszechstronnego wypracowania nowoczesnych podstaw naszej pracy oświatowej pozaszkolnej i dlatego z całą obiektywnością dopuszczać będzie do głosu opinie wszystkich kierunków współczesnej myśli, jeśli tylko wylegitymować się zdołają ze swojego szczerego i bezinteresownego stosunku do tych wielkich ideałów narodowych i kulturalnych, jakie przyświecać muszą zawsze wszelkiej twórczej pracy polskiej zaś pracy oświatowej przede wszystkim (tamże).

W organie Zjednoczonych Towarzystw Oświatowych „Oświacie Polskiej” w 1924 r. z kolei napisano:

„Oświata Polska” ma być zwierciadłem, w którym odbijać się powinny wszelkie wysiłki całego społeczeństwa polskiego w dziedzinie oświaty, szczególnie pozaszkolnej. Naczelny cel; budzenie i pogłębianie świadomości narodowej, szerzenie wiedzy w ogóle, a wiadomości obywatelskich w szczególności, zapoznawanie ze skarbami kultury polskiej i stwarzanie dróg najszerszego wpływu tej kultury na masy, dążenie do formowania typu obywatela polskiego, a przez to wszystko - stwarzanie trwałych podstaw dla własnego państwa (Stemler 1924: 11-12). 
Wyznaczone cele i zadania były realizowane poprzez dobór autorów zamieszczanych tekstów oraz prezentowanie na łamach pism dorobku organizacyjnego oświaty pozaszkolnej dorosłych we wszystkich regionach niepodległej Polski. W tym okresie państwo polskie pozostawiło organizowanie tej pracy organizacjom społecznym, samorządom, samo koncentrowało się na tworzeniu placówek edukacyjnych dla dzieci i młodzieży, by niezwykle wysoki odsetek niepodejmujących edukacji na poziomie szkoły powszechnej zredukować.

Po przewrocie majowym 1926 r. coraz większa stawała się ingerencja państwa w sprawy oświaty pozaszkolnej. Dominujące wychowanie narodowe, obywatelskie stopniowo zastępowano wychowaniem państwowym. W latach 30 . XX w. ideał wychowania państwowego rozumiano jako:

pracę na rzecz etosu państwowego czyli zinternalizowanie tego etosu w psychikę każdej osoby podlegającej oddziaływaniu oświatowemu. Wychowanie państwowe powinno kształtować cechy szczególnie ważne dla państwa. Zaliczano do nich rozumienie spraw państwowych, poczucie współodpowiedzialności za państwo, praworządność, patriotyzm (Smołalski 1994: 69).

W połowie lat 30. ubiegłego wieku w numerze 1 „Pracy Oświatowej” z 1935 r. redakcja napisała:

pismo tego typu jest potrzebne, wypełnia dotkliwą lukę $\mathrm{w}$ dziedzinie pomocy kulturalnej dla oświatowców polskich, borykających się w walce, często ponad siły, z codzienną praktyką, że stanie się źródłem informacyjnym w pracy oświatowej, i że - co najważniejsze, stanie się łącznikiem wewnętrznym dużej już dziś rodziny oświatowej (Od Redakcji 1935: 2).

Zamierzenia te udało się zrealizować, bowiem wielu autorów z różnych regionów Polski przysyłało materiały dotyczące funkcjonowania instytucji oświaty pozaszkolnej.

Struktura wszystkich czasopism ukazujących się w okresie międzywojennym była bardzo zbliżona. Pierwszą część stanowiły teksty związane z zagadnieniami teoretycznymi, przygotowywanymi najczęściej przez osoby ze środowiska naukowego bądź też przez praktyków oświaty dorosłych. We wszystkich periodykach nazwano ją Artykuły bądź Artykuły i rozprawy. W niektórych czasopismach były one obszerne objętościowo („Oświata Pozaszkolna”, „Polska Oświata Pozaszkolna”, „Przewodnik Pracy Społecznej”), a w innych najczęściej krótkie („Przegląd Oświatowy”, „Oświata Polska”, „Przewodnik Oświatowy”). Problematyka podejmowana na ich łamach była zbliżona. Palące potrzeby związane $\mathrm{z}$ alfabetyzacją polskiego społeczeństwa spowodowały, iż wiele tekstów dotyczyło kursów dla dorosłych, ognisk oświatowych, bibliotek i czytelni, uniwersytetów powszechnych i ludowych, działalności kulturalnej. Wszystkie periodyki zawierały Materiały, czyli szerzej 
zanalizowane różne formy pracy oświatowej. W czasopismach różnych wydawców były prezentowane osiągnięcia w zakresie pozaszkolnej pracy oświatowej konkretnych organizacji. Bardzo interesujące były działy Kronika oświatowa, Z ruchu oświatowego $w$ Polsce pozwalające na dokonanie rekonstrukcji rozwoju różnych form pracy oświatowej w Polsce międzywojennej. Nauczycielom i oświatowcom bezpośrednio zaangażowanym w prace z dorosłymi przydatne w ich praktyce były działy Przegląd prasy, Oceny książek, Przegląd literatury wspierające ich w dokształcaniu i doskonaleniu.

Na obszarze całego kraju od początku odzyskania niepodległości rozwijała się ożywiona działalność oświatowa. Tworzono instytucje mające dać formalne uprawnienia dorosłym w zakresie szkoły powszechnej, prowadzono kursy, działalność kulturalno-oświatową. Poczynania te znajdowały odzwierciedlenie we wszystkich periodykach analizowanego okresu. Niezależnie od wydawcy umieszczano informacje o mających się odbyć bądź też już przeprowadzonych formach oświaty pozaszkolnej, których organizatorami były organizacje zróżnicowane światopoglądowo. Szczególnie ważna była praca na wschodnich terenach Rzeczypospolitej, gdzie kwestie braku umiejętności czytania i pisania przybrały największe rozmiary. Przede wszystkim zaangażowani w niej byli nauczyciele szkół powszechnych, najczęściej nieposiadający wiedzy o specyfice kształcenia dorosłych. Dla nich ukazujące się czasopisma miały być wsparciem w tej pracy poprzez prezentowanie specyfiki ucznia dorosłego, metod pracy oświatowej i kulturalnej z tą kategorią odbiorców. Do nich też głównie była kierowana Bibliografia i syntetyczne omówienie niektórych publikacji polskich i zagranicznych dotyczących tej problematyki. Kwestia samokształcenia była bowiem ważna zarówno dla nauczycieli zaangażowanych w oświatę pozaszkolną dorosłych, jak i samych uczestników tejże.

Wszystkie periodyki podejmujące $\mathrm{w}$ okresie dwudziestolecia międzywojennego zagadnienia pozaszkolnej oświaty dorosłych były niezwykle cennymi inicjatywami wydawniczymi. Dzięki nim organizatorzy pracy z dorosłymi mogli poznać jej teoretyczne podstawy i uwarunkowania, śledzić bieżące wydarzenia oświatowo-kulturalne na terenie całego kraju, jak i w nich bezpośrednio uczestniczyć. Odzwierciedlały one profil społeczno-ideologiczny zarówno organizacji, stowarzyszeń będących ich wydawcami, jak i władzy państwowej, lecz ich głównym zadaniem było wspieranie oświatowców w ich trudnej pracy.

\section{Bibliografia}

Banaczkowski P. (1962) Wydział Oświaty Pozaszkolnej Zwiq̨zku Polskiego Nauczycielstwa Szkół Powszechnych, „Przegląd Historyczno-Oświatowy”, nr 3, s. 495-502.

Breitkopff, E. (1986) „Polska Oświata Pozaszkolna” 1924-1934, „Przegląd Historyczno-Oświatowy", nr 4, s. 496-507. 
Działalność instytucji wydawniczych na rzecz oświaty i edukacji w XIX i poczq̨tkach XX wieku (2014) I. Michalska, G. Michalski (red.), Łódź, Wydawnictwo Uniwersytetu Łódzkiego, s. 247-258.

Goriszowski W. (1959) Przegląd ważniejszych czasopism pedagogicznych wychodzacych w Polsce do 1939 r. i od 1945, „Chowanna”, nr 9/10, s. 535-559.

Kopczewski W. (oprac.) (1920) O szkołę polską. Pierwszy ogólnopolski wielki zjazd nauczycielski $w$ dniach 14, 15, 16, 17 kwietnia 1919 r. w Warszawie. Sprawozdanie i streszczenia, Lwów-Warszawa, Książnica Polska.

Kozdrowicz E. (1987) „Przewodnik Pracy Społecznej” 1934-1939, „Przegląd Historyczno-Oświatowy", nr 2, s. 199-211.

Koprianiuk E. (1975) Kierunki rozwoju oświaty pozaszkolnej w latach 1918-1939, „Przegląd Historyczno-Oświatowy”, nr 1, s. 29-49.

Lubczyńska A. (2014) „Miesięcznik Towarzystwa Szkoły Ludowej” (1901-1906) i „Przewodnik Oświatowy" (1907-1939) oraz ich wydawca - Towarzystwo Szkoły ludowej w: Michalska I., Michalski G. (2017) Kierunki wsparcia działalności społeczno-oświatowej w latach trzydziestych XX wieku przez poznańskie czasopismo „Oświata Pozaszkolna" (1934-1937) w: Wielkopolska i Wielkopolanie w dziejach polskiej edukacji, E. Głowacka-Sobiech, K. Kabacińska-Łuczak (red.), Poznań, Wydawnictwo Naukowe Uniwersytetu im. Adama Mickiewicza, s. 501-524.

Możdżeń S., Musiał J. (1981) Bibliografia polskich czasopism pedagogicznych do 1979 r., Kielce, Wyższa Szkoła Pedagogiczna im. J. Kochanowskiego.

Nasze dziesięciolecie (1933) „Polska Oświata Pozaszkolna”, nr 1, s. 1-3.

Od Redakcji (1921) „Oświata Pozaszkolna”, nr 1, s. 1-4.

Od Redakcji (1935) „Praca Oświatowa”, nr 1, s. 1-2.

Radlińska H. (1947) Oświata dorosłych. Zagadnienia, dzieje, formy, pracownicy, organizacja, Warszawa, Wydawnictwo Ludowego Instytutu Oświaty i Kultury.

Radwan W. (1925) Postulaty w sprawie ustroju szkolnictwa w Rzeczypospolitej Polskiej, Warszawa, Nasza Księgarnia.

Sapia-Drewniak E. (2019) „Oświata Pozaszkolna” pierwsze czasopismo andragogiczne w II Rzeczypospolitej (1921-1923), „Przegląd Historyczno-Oświatowy”, nr 1, s. 192-203.

Sławińska E. (1989) Kulturotwórcza rola Towarzystwa Czytelni Ludowych na Pomorzu Gdańskim (1880-1939), Bydgoszcz, Wydawnictwo Uczelniane Wyższej Szkoły Pedagogicznej. 
Smołalski A. (1994) Ideały wychowawcze w polskiej myśli pedagogicznej od XVI w. do końca II Rzeczypospolitej, Opole, Wydawnictwo Uniwersytetu Opolskiego.

Stemler J. (1924) Oświata pozaszkolna, „Oświata Polska”, nr 1, s. 10-16.

Sutyła J. (1982) Miejsce kształcenia dorosłych w systemie oświatowym II Rzeczypospolitej, Wrocław-Warszawa-Kraków-Gdańsk-Łódź, Zakład Narodowy im. Ossolińskich - Wydawnictwo.

Wroczyński R. (1983) Ideologia oświaty pozaszkolnej okresu międzywojennego w świetle miesięcznika „Praca Oświatowa” (1935-1939), „Przegląd Historyczno-Oświatowy”, nr 2, s. 143-163. 